\title{
Occupational mobility and income differentials: The experience of Brazil between 2002 and 2010
}

\author{
Sandro Eduardo Monsueto, Julimar da Silva Bichara and \\ André Moreira Cunba
}

ABSTRACT

Since the start of the twenty-first century, the Brazilian economy has experienced a growth cycle with characteristics unlike those of its previous historical experience, combining growth, macroeconomic stability and distributive progress. In this context, the study aims to analyse the factors and distributive effects of occupational mobility in Brazil, based on data obtained from the Monthly Employment Survey. The results suggest that: (i) mobility has been used in Brazil as a way to raise wages, even when it involves a drop in socio-occupational status; (ii) nonetheless, the wage increase obtained by changing job or occupational segment is smaller for poorer workers than for wealthier ones; and (iii) consequently, mobility helps to increase income, but it also tends to widen wage gaps.

KEYWORDS

JEL CLASSIFICATION

AUTHORS
Employment, labour market, labour mobility, wages, equality, Brazil

$\mathrm{J} 31, \mathrm{~J} 62$

Sandro Eduardo Monsueto is Assistant Professor at the Economic Studies and Research Nucleus (NEPEC) of the Faculty of Management, Accounting Sciences and Economic Sciences of the Federal University of Goiás, Brazil. monsueto@ufg.br

Julimar da Silva Bichara is a Professor at the Autonomous University of Madrid (UAm), Spain. julimar.dasilva@uam.es

André Moreira Cunha is Associate Professor on the Postgraduate Programme in Economics of the Federal University of Rio Grande do Sul (Ufrgs) and a Research Officer at the National Council for Scientific and Technological Development (cNPq), Brazil.andre.cunha@ufrgs.br 


\section{I}

\section{Introduction}

Although Brazil is one of the most unequal countries in the world, since the start of this new century income inequality has been gradually but almost continuously declining, whether measured by the Gini inequality coefficient or through the ratios of the proportions of total income received by the different segments of the income distribution (Barros, De Carvalho and Mendonça, 2010). Another significant feature of this reduction in inequality is that it has coincided with a cyclical upswing in income in a context of relative macroeconomic stability, involving, among other things, moderate inflation, a declining trend in the net public-sector debt, and greater external solvency. There has also been growth in the net supply of jobs, their formalization, and in real wages, while economic poverty has retreated (IPEA, 2010; Ferrari-Filho, Cunha and Bichara, 2014).

There are many factors driving this reduction in income inequality, including the persistence of economic stability (Rocha, 2000), the federal government's conditional cash transfer programmes and a rising trend in labour incomes (Barros, De Carvalho and Mendonça, 2007 and 2010). That virtuous labour-market behaviour could be linked to the vigorous creation of formal jobs, optimization of human capital, reduction in wage discrimination based on gender and skin colour, and a decrease in sectoral and geographic segmentation.

While the importance of the labour market in the development process is not a novelty in economic analysis, it has not been greatly emphasized, particularly in developing countries. The labour market is the key factor explaining how growth is distributed in society, since the distribution of the benefits of growth is closely tied to the quantity and quality of the jobs created during the expansionary period (Paci and Serneels, 2007). Nonetheless, the evolution of that structure through time, in other words labour-market mobility, is also significant. Knowing how workers can gain access to better-paid jobs is fundamental for understanding how the income

$\square$ This study was undertaken as part of the Programme to Promote Economic Development Research (PDE) of the Brazilian Development Bank (BNDES), published in 2010, in the project entitled "The new growth cycle in the Brazilian economy: occupational mobility and income inequality". generated by economic growth is distributed. This makes it necessary to understand the factors that determine occupational mobility, the barriers that exist, the wage premium obtained from mobility, and the effects of that mobility on the distribution of income from work. That is the basic objective of this study.

There is evidence that workers may be using occupational mobility to obtain wage increases, and also as a way of exiting from precarious employment situations, involving informality or a high rate of involuntary unemployment (Holzer, Lane and Vilhuber, 2003; García Pérez and Rebollo Sanz, 2005; Davia, 2006). Nonetheless, those benefits may be non-existent or limited in the face of barriers imposed by labourmarket segmentation. In Brazil, apart from the studies by Oliveira and Machado (2000) and Pinto and Neri (2000), who found differences in the return to mobility between the different population groups, there are few data that adequately show the effect of occupational mobility on income inequality. Accordingly, it is not yet clear whether or not occupational mobility has helped reduce inequality, particularly during the most recent period. To contribute to the debate, this article aims to analyse the factors that affect occupational mobility and verify whether this involves socioeconomic progress, and to assess its effects on income inequality in Brazil, using data from the Monthly Employment Survey for the period from 2002 to 2010 .

The specific objective is to analyse the wagedifferential effect of mobility, in terms of labour-market segmentation (which generates differences relating to socioeconomic and occupational progress, for example) and differential returns to mobility, observing whether or not occupational movements alter the income distribution by reducing wage differentials. New data on the effect of human capital are put forward and an analysis is made of the socioeconomic destination of the workers, to ascertain whether mobility is being used to move ahead in the social structure and in the distribution of income, or whether distribution is limited by labourmarket segmentation. This approach to mobility and inequality makes it possible to evaluate the size of the group of workers who, despite the occupational changes they make, fail to break out of structure of small wage 
increases and little technological growth, with relatively less institutional protection. Following this introduction, section II makes a brief review of the bibliography of the relation between occupational mobility and wages.
Section III then describes the methodology, the data, the results, and the corresponding analysis; and, lastly, section IV sets forth final thoughts summarizing the main results of the study.

\section{II \\ Literature review: empirical data and their political consequences}

There is abundant empirical data on occupational mobility and its effects on wages, particularly for the United States but also, more recently, for European countries and a few Latin American ones too (Beccaria and Maurizio, 2003). A study by Paci and Serneels (2007), which addresses the relation between the labour market and development, considers the structure of the labour market and occupational mobility to be key variables for explaining the income distribution. In the case of Brazil, the main studies are Pinto and Neri (2000) and Oliveira and Machado (2000), which use longitudinal data from the Monthly Employment Survey conducted by the Brazilian Geographical and Statistical Institute (IBGE).

Most empirical studies stress the role of the occupational distribution of workers as an essential tool for explaining wages. Accordingly, social and labour-market factors, discrimination, and differences in investment in or access to human capital are topics that are inherent to the debate on income distribution in Brazil. From that standpoint, the labour market simply reflects the social inequalities that already exist in the country (Barros and Mendonça, 1995), while also acting as a creator of inequality, because it is characterized by segmentation and by both gender and racial discrimination (Oliveira and Ribeiro, 1998; Oliveira, 1998 and 2003; Soares and Oliveira, 2004; Matos and Machado, 2006). Nonetheless, the Brazilian labour market can also provide a way out of situations involving very low incomes or poverty (Barros, Machado and Mendonça, 1997).

The international literature stresses the role of human capital, both specific and general, in explaining occupational mobility and the associated wage outcomes. Booth and Francesconi (1999), for example, note that the length of time spent in the labour market has a negative effect on the mobility of British workers, and that the duration of a specific employment experience is negatively correlated with internal changes. The same results have been found in Brazil (Orellano and Picchetti, 2001; Menezes-Filho, 2004; Flore and Menezes-Filho, 2008). Nonetheless, higher education can apparently reduce the probability of mobility (Kambourov and Manovskii, 2004). This result is also found when considering specific human capital, represented by the training received inside the firm, owing to the rise in opportunity cost (Dolton and Kidd, 1998).

Occupational mobility also depends apparently on the economic sector being considered, and its technological level (Zimmermann, 1998), and it can be related to firm size (Cheng and Kalleberg, 1996). In the research undertaken, differences have been found in mobility patterns between different population groups, genders, races and income levels. In general, it would seem that mobility is higher among men than among women (Gabriel, 2003; Parrado and Wolff, 1999), and that the higher-income groups are more stable (Parrado, Caner and Wolff, 2007). Occupational mobility towards high-paid jobs is also somewhat limited, and in such cases the movement would be hindered by discrimination, partial information, deficient employment networks, and agents' preferences (Holzer, Lane and Vilhuber, 2003).

This article aims to highlight the effect of occupational mobility on wage levels; and, in this connection, mobility seems to help improve the income distribution (Fitzenberger and Kunze, 2005) and may even boost wage growth (García Pérez and Rebollo Sanz, 2005). As noted above, there are very few studies on occupational mobility and its effects on income distribution in developing countries. One good example, however, is the study by Paci and Serneels (2007), which reports results for a number of developing countries and shows that there are significant barriers to occupational mobility in the countries of the Middle East and North Africa, according to an analysis of mobility between formal and informal segments. These authors also state 
that there are major barriers to upward mobility among self-employed workers in Mexico, which are determined by education and access to capital. In another study on Ethiopia, Ghana and the United Republic of Tanzania, they analysed the effect of mobility between sectors defined according to occupational status, and found strong barriers to mobility; and, when mobility exists, the main factor driving wage growth is the size of the firm.

As in the previous cases, a key feature of the Brazilian labour market is its segmentation between formal and informal workers. This gives rise to clear differences, because occupational mobility is less than among formal workers and, particularly, among those with most experience (Neri and others, 1997). Moreover, the mobility pattern is different, depending on gender and race, so that women and Afrodescendants in Brazil are over-represented in low-paid jobs and in generally unfavourable employment tracks, such as downward mobility and declining wages (Oliveira and Machado, 2000; Pinto and Neri, 2000). For these groups, therefore, mobility would be synonymous with a mere turnover of labour, involving frequent job changes without adding skills or increasing productivity.
The occupational structure is thus relevant for explaining the wage gap. The way workers change job or succeed in moving out of a given occupational segment can change the configuration of the income distribution. Moreover, occupational segmentation and segregation are phenomena that restrict worker mobility and mean that, among other things, a change of job only reproduces through time the unequal structure of labour allocation, without involving progress in terms of the individual's social condition (Fitzenberger and Kuzne, 2005; Maltseva, 2005). In other words, wage inequality can be affected both by the occupational structure and by worker movements that alter the structure. Nonetheless, as shown in the literature review, the role played by occupational mobility during the recent period of the Brazilian economy is not yet clear. In that context, this article seeks to improve understanding of occupational mobility and its effects on the socioeconomic structure of workers and the distribution of income in Brazil. It also seeks to determine whether mobility has been used by the worker to progress within the income distribution, or whether it is merely reproducing a segmented labour market.

\section{III}

\section{Data and methodology}

To fulfil the objective of this study, microdata from the Monthly Employment Survey have been used to compare workers' situations in terms of their employment characteristics, education level, age or wage, through a panel of monthly data in six of the country's metropolitan regions: Belo Horizonte, Porto Alegre, Recife, Rio de Janeiro, Salvador and São Paulo. The econometric strategy is divided into two stages. The first analyses factors driving mobility between jobs or occupational segments; and the second estimates the effects of this mobility on the income distribution.

Using a panel from the Monthly Employment Survey makes it possible to compare information on the job held by the individual at two different points in time, and thus obtain four types of results with respect to workers in employment, without considering people who leave the sample:

(i) the individual in question had the same job in both periods;

(ii) he or she had different jobs; (iii) was unemployed, or

(iv) was inactive.

The occupational mobility rate expresses the percentage of employed workers who had a different job in the second period from that declared in the first. Thus, the first part of research entails determining the probability that an individual changes his/her job.

Jobs are classified in socio-employment status groups, using a methodology based on average hourly wages, education level, informality and similarity between activities, inspired in the work of Jannuzzi (2004), as shown in table 1. This classification can be used to describe the socio-employment structure of the Brazilian labour market, and also to analyse the workers' occupational mobility (upwards or downwards) in socioeconomic terms (wage and social status).

To capture those multiple changes, the study estimates the following multinomial logit model, which expands the binary choice models: 
TABLE 1

Brazil: socio-employment status categories and typical jobs in the Monthly Employment Survey, 2002-2010

(Reais and years)

\begin{tabular}{|c|c|c|c|}
\hline Socio-employment status & $\begin{array}{l}\text { Average } \\
\text { hourly wage } \\
\qquad(R \$)\end{array}$ & $\begin{array}{l}\text { Average } \\
\text { education level } \\
\text { (years'schooling) }\end{array}$ & Some typical jobs \\
\hline 1. Higher & 14.50 & 10.18 & $\begin{array}{l}\text { Managers; company directors, laboratory technicians, } \\
\text { higher-grade professionals, navigation professionals and } \\
\text { supervisors. }\end{array}$ \\
\hline 2. Middle & 6.43 & 9.08 & $\begin{array}{l}\text { Middle ranking technicians generally; jewellers and } \\
\text { goldsmiths; industrial supervisors; industrial operators; } \\
\text { navigation technicians, transport workers and salespeople. }\end{array}$ \\
\hline 3. Lower & 3.86 & 7.14 & $\begin{array}{l}\text { Hotel, food, security workers, among others; farm } \\
\text { supervisors and workers; commercial and residential } \\
\text { workers; domestic employees; travelling sales persons, } \\
\text { commercial suppliers and personal services. }\end{array}$ \\
\hline
\end{tabular}

Source: Monthly Employment Survey, 2002-2010.

$$
\operatorname{Pr}\left(Y_{i}=j\right)=\frac{e^{\beta_{j}^{\prime} x_{i}}}{1+\sum_{k=0}^{2} e^{\beta_{j}^{\prime} x_{i}}}, \quad j=0,1,2
$$

where $\operatorname{Pr}$ represents the probability that the individual experiences event $j ; x_{i}$ is the vector of expansion variables, and $\beta$ is the vector of parameters to be estimated. The model was used by Budría and Pereira (2004), for example, to analyse the probability that workers in Portugal participate in training programmes; and by Souza and Lima (2011), to investigate the probability that a person is unemployed, has a formal job, or has an informal job in Brazil.

Variables explaining the probability of achieving upward or downward socio-employment mobility include demographic, human capital and labour-market factors; and the following model is estimated to capture elements of the two main groups of theories explaining mobility (human capital and segmented markets):

$$
\begin{gathered}
\operatorname{Pr}\left(Y_{i}=j\right)=f\left(\text { sex, colour, head, age, } \sum\right. \text { skill, } \\
\text { formal, } \left.\sum \text { sector, } \sum \text { region, } \sum \text { year }\right)
\end{gathered}
$$

where $y$ takes the value 0 if the worker remains in the same category in the two periods considered, 1 if he/ she rises in category, and 2 if he/she moves to a lower category; sex is a binary variable (male or female); colour takes the value 1 for persons of white race and 0 in other cases; head is a dummy variable that captured the worker's status in the family; age is the worker's age; skill represents the worker's education level; ${ }^{1}$ formal is a binary variable of value 1 in the case of formal workers; sector represents a set of dummy variables for the sectors of economic activity; ${ }^{2}$ region corresponds to dummy variables representing the six metropolitan regions, and year refers to the dummy variables of annual effects.

After estimating the occupational mobility factors, a quantile regression analysis is made (Koenker and Basset, 1978) of the effect of mobility on the wage level and distribution of wage incomes. Quantile regressions make it possible to compare marginal effects, or wage premia associated with the different factors, of the wealthiest and poorest workers within the wage distribution. This, in turn, makes it possible to verify whether mobility has a differential impact according to the individual's income level. For example, if poorer workers gain higher premia for moving up the socio-employment ladder, then mobility can help reduce wage differences between the different income brackets. To determine whether the differences are real and significant, interquantile regressions can be used (Koenker, 2000).

The estimated model, both for the regressions conditional on the quantiles and for the inter-quantile regressions, are given by the following equation:

\footnotetext{
${ }^{1}$ Unskilled (up to three years' schooling); low skilled (4 to 7 years'); semiskilled (8 to 10 years'), and skilled (more than 10 years').

2 Basic products; manufacturing; and construction sectors; tertiary sector and other activities.
} 


$$
\begin{gathered}
\ln \left(w_{2}\right)=f\left(\text { sex, colour, head, age, age }{ }^{2}, \sum\right. \text { skill, formal, } \\
\left.\sum \text { sector, } \sum \text { region, } \sum \text { year, upward, downward }\right)
\end{gathered}
$$

where $w_{2}$ is the wage received in the second period (following the decision to change job, or not as the case may be); sex, colour, head, age, skill, formal, sector, region and year are defined as above; "upward" and "downward" are dummy variables indicating the workers' direction of movement, taking as a reference those who change their socio-employment segment. Thus, within the inter-quantile regression model, if ability has a significant negative effect, it means that the occupational movements help reduce the wage difference between the quantiles considered and, therefore, reduce inequality. The quantiles analysed are the 10th, 25th, 75th and 90th, because the first two capture the incomes of the poorest workers, and the two last represent individuals with the highest hourly wages.

The analysis covers the period 2002-2010 and used a sample of private-sector wage-earners aged between 18 and 65 (including domestic employees) who had a job in the reference week. Mobility is analysed by comparing the information from the fourth and eighth interviews; and the panels are combined as proposed by Ribas and Soares (2008). The monetary values were converted into reais at December 2010 prices, as indicated by Corseuil and Foguel (2002). In total, the database contains 79,736 observations, as noted in table 2 , which also presents brief statistics on the database used. The variance matrix for each model was estimated using the bootstrap technique to control for heteroscedasticity (Buchinsky, 1998). The results of the econometric analysis are shown and their analytical consequences are studied below.

TABLE 2

Brazil: average of descriptive statistics, 2002-2010

\begin{tabular}{|c|c|c|c|}
\hline & Average & Poorest $25 \%$ & Wealthiest $25 \%$ \\
\hline Workers who changed job & 29.0 & 27.7 & 32.4 \\
\hline Workers who changed segment & 15.3 & 12.6 & 19.7 \\
\hline Hourly wage in the second period (reais) & 6.2 & 2.3 & 14.4 \\
\hline Men & 59.9 & 45.0 & 70.9 \\
\hline Persons of white race & 54.7 & 38.6 & 73.3 \\
\hline Heads of family & 51.9 & 40.4 & 63.9 \\
\hline Mean age & 35.7 & 34.8 & 37.9 \\
\hline \multicolumn{4}{|l|}{ Skill level } \\
\hline Unskilled (up to 3 years' schooling) & 7.0 & 12.6 & 1.6 \\
\hline Low skilled (4-7 years' schooling) & 23.2 & 33.0 & 8.6 \\
\hline Semiskilled (8-10 years' schooling) & 19.7 & 23.7 & 10.6 \\
\hline Skilled (over 10 years' schooling) & 50.1 & 30.7 & 79.3 \\
\hline Formality rate & 79.3 & 66.6 & 87.6 \\
\hline \multicolumn{4}{|l|}{ Sector of economic activity } \\
\hline Basic products & 9.0 & 8.8 & 8.2 \\
\hline Manufacturing & 14.3 & 6.1 & 23.4 \\
\hline Construction & 5.4 & 5.7 & 4.4 \\
\hline Tertiary & 70.1 & 78.2 & 62.1 \\
\hline Other activities & 1.3 & 1.2 & 2.0 \\
\hline \multicolumn{4}{|l|}{ Metropolitan regions } \\
\hline Recife & 5.8 & 10.8 & 2.7 \\
\hline Salvador & 7.7 & 12.8 & 6.0 \\
\hline Belo Horizonte & 17.7 & 20.4 & 15.1 \\
\hline Rio de Janeiro & 27.3 & 32.0 & 23.2 \\
\hline São Paulo & 25.65 & 13.3 & 36.7 \\
\hline Porto Alegre & 15.9 & 10.82 & 16.29 \\
\hline No. of observations & 79736 & 19992 & 19906 \\
\hline
\end{tabular}

(Percentages, reais and years' schooling)

Source: prepared by the authors on the basis of data from the Monthly Employment Survey. 


\section{IV}

\section{Results and analysis}

This section presents the results of the analysis of the effect of mobility on wage differentials, using data from the Monthly Employment Survey; and it shows the results of the probability model of occupational change and regressions of the wage estimated using quantile regressions.

\section{Socio-employment mobility factors}

The socio-employment categories used are based on average hourly wages, education level, and the informality rate within each job, grouped into three levels: higher, medium and lower. Bearing in mind that the labour market is the main source of income, and the way workers enter this market can determine their horizon of opportunities, these categories can be used to represent an overview of the country's socioeconomic structure. Table 3 shows that the socio-employment structure remained relatively stable in the decade of 2000, and the only feature to note is the two percentage point rise in the number of workers in activities pertaining to the lower segment.

TABLE 3

\section{Brasil: socio-employment categories, 2002-2009 \\ (Percentages)}

\begin{tabular}{lccc}
\hline Year & Upper & Middle & Lower \\
\hline 2002 & 11.5 & 42.0 & 46.4 \\
2003 & 11.0 & 40.9 & 48.1 \\
2004 & 11.0 & 39.8 & 49.2 \\
2005 & 11.0 & 40.5 & 48.5 \\
2006 & 10.8 & 41.3 & 47.8 \\
2007 & 10.4 & 40.9 & 48.7 \\
2008 & 11.6 & 40.4 & 48.0 \\
2009 & 10.3 & 40.3 & 49.4 \\
Total & 10.9 & 40.7 & 48.4 \\
\hline
\end{tabular}

Source: prepared by the authors on the basis of data from the Monthly Employment Survey.

Considering the original job classification in the Monthly Employment Survey, on average nearly 30\% of workers had a different job than declared initially. Among those who changed their job: (i) $53 \%$ moved to another socio-employment segment; and (ii) $47 \%$ remained in the same segment. The mobility rate between segments is, on average, $15 \%$ for the entire sample, because $7.6 \%$ of workers displayed upward mobility, in other words they left a lower occupational segment and moved to a higher one, whereas $7.7 \%$ displayed downward mobility.

The results of the probability model represented by equation (2) are shown in table 4 , taking socioemployment immobility as the reference the situation. As the categories are formed by taking account of the workers' education levels, among other factors, two models are prepared - with and without the binary variables of skill and formality-. The results are expressed in terms of marginal effects and, for reasons of space, the annual dummy variables are omitted, although they can be obtained from the authors (this procedure will be used also in the other tables showing the econometric results).

The two estimated models produce similar results, so the signs of the marginal effects remain consistent. Women are less likely to change their occupation, while men are more flexible both for upwards and for downward mobility. A similar result is observed when analysing the effect of the dummy variable representing skin colour, because white workers display greater mobility than those of other races, as also reported by Pinto and Neri (2000), who used data from the Monthly Employment Survey for the 1990s. Among heads of family, the positive sign and significant status of the marginal effect on the probability of immobility may indicate greater risk aversion among individuals who are responsible for sustaining a family.

In the case of human-capital factors, age and education display different signs, which confirms the hypothesis that different forms of human capital have differentiated effects on occupational mobility (Mincer and Jovanovic, 1979). Age, which can be interpreted as representing experience and, thus, specific human capital, indicates that the older individuals tend to remain in the same occupational segment. In contrast, workers with higher levels of education or general human capital are more flexible and change socio-employment segment more easily.

On average, formal and informal workers both have a similar rate of mobility between jobs, of around $29 \%$ for both groups. Nonetheless, the estimated model shows 


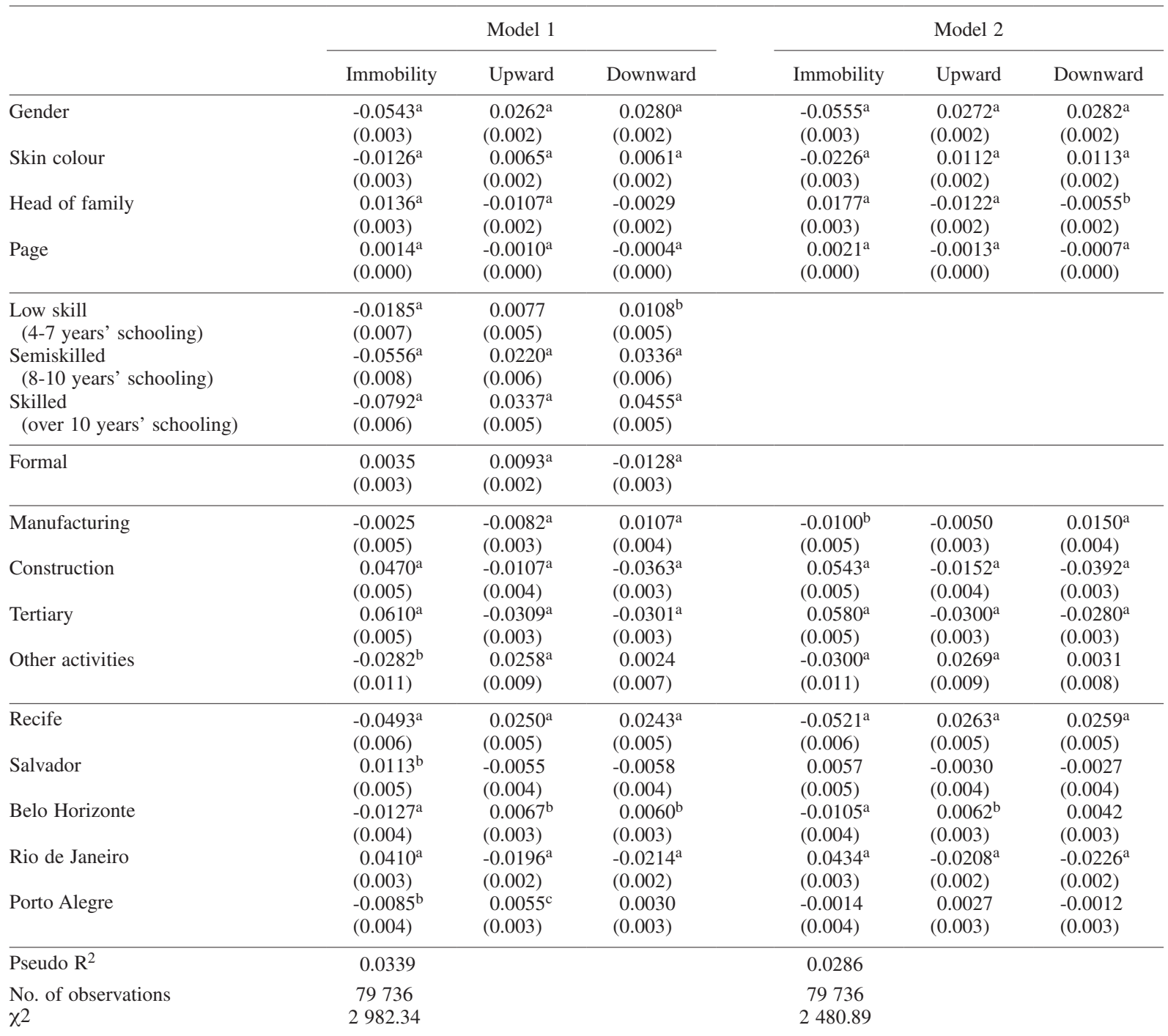

Source: prepared by the authors on the basis of data from the Monthly Employment Survey.

a $\mathrm{p}<0.01$.

b $\mathrm{p}<0.05$.

c $\mathrm{p}<0.10$.

Note: annual dummy variables suppressed. Robust standard deviations in parentheses.

that this mobility does not produce the same results when the destinations of the workers are considered. Those in the formal sector who change their job generally move upwards to occupations in better segments, whereas the mobility of informal workers more often tends to be downwards. Thus, in addition to promoting job stability, possession of a work contract could be promoting additional protection for people. These results suggest that the worker's formalization can be seen as a factor that promotes career advancement, and consequently, a rising socio-employment status.

The results show that mobility and flexibility, understood respectively as the flow of workers between jobs or segments and the degrees of freedom provided by the market for these changes and also for the hiring or firing of labour, are closely related topics. While, on the one hand, the analysis corroborates the results, for example, of Barros and others (1997), which reveals a 
considerable degree of flexibility in the labour market in Brazil, it also provides additional information by showing that the effect of that flexibility is not homogeneous between groups of workers. Informal wage earners who, in principle, are the most flexible, are not benefiting from that flexibility as much as workers who are institutionally protected by the employment contract. This finding suggests that the elimination or reduction of institutional protection do not seem consistent with policies to bring about a redistribution of income through the labour market.

Assuming true the hypothesis that occupational integration is one of the main factors determining income levels, the manner and velocity with which workers move from one occupational segment to another may also indicate changes in the country's income distribution. The next subsection presents the results of an estimation of wage equations that captures the effect of socio-employment mobility across the quantiles of the hourly wage distribution.

\section{Wage determination: quantile regressions}

Quantile regressions form the basis for determining the return to mobility in each income bracket. Conditional regressions were estimated with respect to the 10th, 25 th, 75 th and 90th quantiles. The first two capture the poorest workers, while the last two represent individuals with the highest hourly wages.

The results are shown in table 5, which, alongside the general model, also presents an alternative estimation without the education and formality variables, since these form the basis for the aggregation of the occupation segments and could be unduly correlated with the mobility dummy variables. For each personal or labourmarket characteristic in the traditional quantile variables, marginal incomes are calculated through the first derivative applied to the equation of the conditional distribution of the hourly wage.

The typical variables of the Mincer equations have the expected signs (Corseuil, 2002), but with different intensities in the different conditional quantiles. The binary variable representing gender, for example, captures the difference between men and women in the labour market, whereas the variable relating to skin colour shows the wage differential between white race individuals and those of other races. In both cases, the marginal effects increase as one moves up the conditional distribution of hourly wage, which shows that the differences between the demographic groups intensify among the wealthier workers. With regard to the skill of the workers, two conclusions can be drawn from the estimated results. Firstly, taking unskilled workers as a reference, the marginal effects rise for higher skill levels. Secondly, workers from higher quantiles report greater marginal effects, in other words, more opportunities or greater facility to turn the acquired skill into a wage. These results are consistent both with the earliest studies that used quantile regressions in Brazil, such as de Maciel, Campelo and Raposo (2001), and with more recent analyses, such as Sampaio (2009). Possession of an employment contract seems to lose force in explaining the income level of workers with higher wages, because, for them, other factors have an influence beyond formalization of the job through a contract (Pianto and Pianto, 2002).

In the case of mobility between socio-employment segments, the positive sign and significant status in most cases show that, in the Brazilian labour market, mobility has the effect of increasing individuals' wages, even when the movement is to a lower socio-employment segment. These results show that when two workers are compared, one of whom recently changed job while the other has remained for longer in the same activity, the first tends to have a higher hourly wage. In this regard, mobility in Brazil seems to be being used as a strategy for obtaining a higher wage, rather than length of time in the job or employment category (Fitzenberger and Kunze, 2005).

Nonetheless, the positive outcome of mobility should not necessarily be seen as contradicting expectations according to length of service. Albuquerque (2008) suggests that, at least in the case of the youngest workers, turnover is related to wage increases, which can also be interpreted as moving up professionally. Moreover, time in a job also has a positive sign, which shows that the more experienced workers are generally paid better. In this regard, more specific research could be undertaken by age groups, to compare the effects of mobility between young people entering the labour market and other older people with greater professional experience.

When the long-term effects of the quantiles are analysed, socio-employment mobility seems to have little repercussion on the wage of the poorest workers, but becomes more important in the two middle quantiles of the distribution. For the wealthiest workers, mobility, even downward, entails a positive wage premium. In the occupational-matches approach (McLaughlin, 1991), workers with the highest wages and, generally, the best jobs, only decide to change job when that decision benefits them, which demonstrates the greater presence of voluntary changes in this group. The results reported here thus show that mobility could reflect the fact that 
TABLE 5

Brazil: quantile equations of wages, 2002-2010

\begin{tabular}{|c|c|c|c|c|c|c|c|c|}
\hline \multirow{2}{*}{ Quantiles } & \multicolumn{4}{|c|}{ Model 1} & \multicolumn{4}{|c|}{ Model 2} \\
\hline & 10th & 25 th & 75 th & 90th & 10th & 25 th & 75 th & 90 th \\
\hline \multirow[t]{2}{*}{ Gender } & $0.1216^{\mathrm{a}}$ & $0.1524^{\mathrm{a}}$ & $0.1991^{\mathrm{a}}$ & $0.1927^{\mathrm{a}}$ & $0.1333^{\mathrm{a}}$ & $0.1739^{a}$ & $0.2085^{\mathrm{a}}$ & $0.1844^{\mathrm{a}}$ \\
\hline & $(0.0048)$ & $(0.0052)$ & $(0.0060)$ & $(0.0108)$ & $(0.0052)$ & $(0.0039)$ & $(0.0057)$ & $(0.0123)$ \\
\hline \multirow[t]{2}{*}{ Skin colour } & $0.0821^{\mathrm{a}}$ & $0.1085^{\mathrm{a}}$ & $0.2321^{\mathrm{a}}$ & $0.2749^{a}$ & $0.1056^{\mathrm{a}}$ & $0.1468^{a}$ & $0.4381^{\mathrm{a}}$ & $0.7193^{\mathrm{a}}$ \\
\hline & $(0.0048)$ & $(0.0045)$ & $(0.0068)$ & $(0.0084)$ & $(0.0046)$ & $(0.0037)$ & $(0.0073)$ & $(0.0091)$ \\
\hline \multirow{2}{*}{ Head of family } & $0.0754^{\mathrm{a}}$ & $0.0857^{\mathrm{a}}$ & $0.1452^{\mathrm{a}}$ & $0.1804^{\mathrm{a}}$ & $0.0526^{\mathrm{a}}$ & $0.0588^{\mathrm{a}}$ & $0.1102^{\mathrm{a}}$ & $0.1714^{\mathrm{a}}$ \\
\hline & $(0.0042)$ & $(0.0050)$ & $(0.0060)$ & $(0.0092)$ & $(0.0053)$ & $(0.0045)$ & $(0.0081)$ & $(0.0146)$ \\
\hline \multirow{2}{*}{ Age } & $0.0054^{\mathrm{a}}$ & $0.0081^{\mathrm{a}}$ & $0.0172^{\mathrm{a}}$ & $0.0206^{\mathrm{a}}$ & $0.0013^{a}$ & $0.0029^{a}$ & $0.0095^{a}$ & $0.0154^{\mathrm{a}}$ \\
\hline & $(0.0002)$ & $(0.0002)$ & $(0.0002)$ & $(0.0004)$ & $(0.0003)$ & $(0.0002)$ & $(0.0003)$ & $(0.0006)$ \\
\hline \multirow{2}{*}{$\begin{array}{l}\text { Low skill } \\
\text { (4-7 years of schooling) }\end{array}$} & $0.0982^{\mathrm{a}}$ & $0.1116^{\mathrm{a}}$ & $0.1459^{a}$ & $0.1508^{a}$ & & & & \\
\hline & $(0.0083)$ & $(0.0058)$ & $(0.0105)$ & $(0.0123)$ & & & & \\
\hline \multirow{2}{*}{$\begin{array}{l}\text { Semiskilled } \\
\text { (8-10 years of schooling) }\end{array}$} & $0.1773^{\mathrm{a}}$ & $0.2017^{\mathrm{a}}$ & $0.2968^{\mathrm{a}}$ & $0.3310^{\mathrm{a}}$ & & & & \\
\hline & $(0.0063)$ & $(0.0070)$ & $(0.0090)$ & $(0.0130)$ & & & & \\
\hline \multirow{2}{*}{$\begin{array}{l}\text { Skilled } \\
\quad \text { (over } 10 \text { years) }\end{array}$} & $0.3408^{a}$ & $0.4343^{\mathrm{a}}$ & $0.8844^{\mathrm{a}}$ & $1.1918^{a}$ & & & & \\
\hline & $(0.0068)$ & $(0.0078)$ & $(0.0101)$ & $(0.0131)$ & & & & \\
\hline \multirow[t]{2}{*}{ Formal } & $0.2807^{\mathrm{a}}$ & $0.2116^{\mathrm{a}}$ & $0.1356^{\mathrm{a}}$ & $0.1116^{\mathrm{a}}$ & & & & \\
\hline & $(0.0060)$ & $(0.0058)$ & $(0.0054)$ & $(0.0098)$ & & & & \\
\hline \multirow[t]{2}{*}{ Manufacturing } & $0.1270^{\mathrm{a}}$ & $0.1585^{\mathrm{a}}$ & $0.1993^{\mathrm{a}}$ & $0.1906^{\mathrm{a}}$ & $0.1514^{\mathrm{a}}$ & $0.1989^{a}$ & $0.3371^{\mathrm{a}}$ & $0.2929^{\mathrm{a}}$ \\
\hline & $(0.0080)$ & $(0.0093)$ & $(0.0094)$ & $(0.0174)$ & $(0.0111)$ & $(0.0079)$ & $(0.0156)$ & $(0.0211)$ \\
\hline \multirow[t]{2}{*}{ Construction } & $0.0633^{\mathrm{a}}$ & $0.0617^{\mathrm{a}}$ & $0.0677^{\mathrm{a}}$ & $0.0855^{\mathrm{a}}$ & $-0.0674^{\mathrm{a}}$ & $-0.0390^{a}$ & -0.0295 & -0.0203 \\
\hline & (0.0106) & $(0.0096)$ & $(0.0142)$ & $(0.0207)$ & $(0.0130)$ & $(0.0095)$ & $(0.0198)$ & $(0.0325)$ \\
\hline \multirow[t]{2}{*}{ Tertiary } & $-0.0174^{b}$ & -0.0042 & $0.0118^{\mathrm{c}}$ & 0.0056 & $-0.0212^{b}$ & $0.0076^{\mathrm{b}}$ & $0.0491^{\mathrm{a}}$ & 0.0107 \\
\hline & $(0.0070)$ & $(0.0061)$ & $(0.0066)$ & $(0.0132)$ & $(0.0084)$ & $(0.0034)$ & $(0.0156)$ & $(0.0155)$ \\
\hline \multirow{2}{*}{ Other activities } & -0.0302 & $0.0641^{\mathrm{a}}$ & $0.2412^{\mathrm{a}}$ & $0.2929^{a}$ & $-0.0975^{a}$ & -0.0217 & $0.4702^{\mathrm{a}}$ & $0.5001^{\mathrm{a}}$ \\
\hline & $(0.0257)$ & $(0.0241)$ & $(0.0392)$ & $(0.0490)$ & $(0.0223)$ & $(0.0345)$ & $(0.0505)$ & $(0.0698)$ \\
\hline \multirow[t]{2}{*}{ Recife } & $-0.3474^{a}$ & $-0.3876^{\mathrm{a}}$ & $-0.4731^{\mathrm{a}}$ & $-0.4999^{a}$ & $-0.3103^{a}$ & $-0.3484^{a}$ & $-0.4691^{a}$ & $-0.5422^{a}$ \\
\hline & $(0.0124)$ & $(0.0087)$ & $(0.0135)$ & $(0.0180)$ & $(0.0145)$ & $(0.0066)$ & $(0.0156)$ & $(0.0282)$ \\
\hline \multirow[t]{2}{*}{ Salvador } & $-0.3163^{a}$ & $-0.3198^{\mathrm{a}}$ & $-0.3210^{\mathrm{a}}$ & $-0.3438^{\mathrm{a}}$ & $-0.2797^{a}$ & $-0.2865^{a}$ & $-0.2120^{\mathrm{a}}$ & $-0.1779^{a}$ \\
\hline & $(0.0070)$ & $(0.0074)$ & $(0.0113)$ & $(0.0168)$ & $(0.0117)$ & $(0.0063)$ & $(0.0168)$ & $(0.0273)$ \\
\hline \multirow[t]{2}{*}{ Belo Horizonte } & $-0.1583^{a}$ & $-0.1629^{a}$ & $-0.1832^{a}$ & $-0.2110^{\mathrm{a}}$ & $-0.1302^{a}$ & $-0.1575^{a}$ & $-0.2166^{a}$ & $-0.2923^{a}$ \\
\hline & $(0.0066)$ & $(0.0048)$ & $(0.0084)$ & $(0.0134)$ & $(0.0054)$ & $(0.0044)$ & $(0.0111)$ & $(0.0187)$ \\
\hline \multirow{2}{*}{ Rio de Janeiro } & $-0.1647^{a}$ & $-0.1689^{a}$ & $-0.1956^{a}$ & $-0.2107^{a}$ & $-0.1686^{a}$ & $-0.1839^{a}$ & $-0.2396^{a}$ & $-0.3270^{a}$ \\
\hline & $(0.0063)$ & $(0.0031)$ & $(0.0090)$ & $(0.0109)$ & $(0.0044)$ & $(0.0051)$ & $(0.0151)$ & $(0.0142)$ \\
\hline \multirow[t]{2}{*}{ Porto Alegre } & $-0.0703^{a}$ & $-0.0998^{\mathrm{a}}$ & $-0.2224^{\mathrm{a}}$ & $-0.2685^{\mathrm{a}}$ & $-0.0688^{a}$ & $-0.1052^{a}$ & $-0.3415^{a}$ & $-0.5461^{\mathrm{a}}$ \\
\hline & $(0.0077)$ & $(0.0045)$ & $(0.0068)$ & $(0.0120)$ & $(0.0066)$ & $(0.0061)$ & $(0.0142)$ & (0.0209) \\
\hline \multirow[t]{2}{*}{ Upward } & 0.0089 & $0.0197^{\mathrm{a}}$ & $0.0470^{\mathrm{a}}$ & 0.0121 & 0.0108 & $0.0362^{\mathrm{a}}$ & $0.1401^{\mathrm{a}}$ & $0.0996^{\mathrm{a}}$ \\
\hline & $(0.0070)$ & $(0.0071)$ & $(0.0162)$ & $(0.0190)$ & $(0.0114)$ & $(0.0077)$ & $(0.0115)$ & $(0.0199)$ \\
\hline \multirow[t]{2}{*}{ Downward } & -0.0063 & -0.0031 & $0.0277^{b}$ & $-0.0212^{c}$ & -0.0003 & $0.0183^{\mathrm{a}}$ & $0.1261^{\mathrm{a}}$ & $0.0877^{\mathrm{a}}$ \\
\hline & $(0.0081)$ & $(0.0061)$ & $(0.0109)$ & $(0.0127)$ & $(0.0074)$ & $(0.0058)$ & $(0.0127)$ & $(0.0178)$ \\
\hline \multirow[t]{2}{*}{ Constant } & $0.0972^{\mathrm{a}}$ & $0.2104^{\mathrm{a}}$ & $0.3357^{\mathrm{a}}$ & $0.5075^{\mathrm{a}}$ & $0.6159^{a}$ & $0.7451^{\mathrm{a}}$ & $1.0699^{\mathrm{a}}$ & $1.3469^{a}$ \\
\hline & $(0.0137)$ & $(0.0141)$ & $(0.0147)$ & $(0.0215)$ & $(0.0145)$ & $(0.0100)$ & $(0.0243)$ & $(0.0334)$ \\
\hline Pseudo $\mathrm{R}^{2}$ & 0.1819 & 0.1749 & 0.2393 & 0.3025 & 0.1092 & 0.1041 & 0.1166 & 0.1515 \\
\hline No. of observations & 79736 & 79736 & 79736 & 79736 & 79736 & 79736 & 79736 & 79736 \\
\hline
\end{tabular}

Source: prepared by the authors on the basis of data from the Monthly Employment Survey.

a $\mathrm{p}<0.01$.

b $\mathrm{p}<0.05$.

c $\mathrm{p}<0.10$.

Nota: annual dummy variables are suppressed. Robust standard deviations obtained by bootstrapping in parentheses. 
the worker has found new occupational matches that give rise to greater productivity. Among the poorest, in contrast, involuntary mobility may be more frequent, as a result of the firm's perception that the worker's productivity is below expectations. It would therefore be worth conducting additional studies to verify whether mobility among the poorest workers provides fewer benefits, precisely owing to the possibly greater incidence of forced occupational changes among them.

When the results are broken down according to the type of labour contract, table 6 shows that the marginal effects of socio-employment mobility are significant for workers who have a signed employment contract, including those located at the top end of the wage distribution. Among informal workers, socio-employment mobility only produces positive and significant effects for individuals with a higher hourly wage. This result seems to show that informal workers, who are supposedly the most flexible, do not benefit financially from that flexibility; and this reinforces the idea that, for this group, mobility is merely synonymous with labour turnover.

These analyses of data from the Monthly Employment Survey make it possible not to reject the hypothesis that mobility between jobs and occupational segments has a significant effect on workers wages, as indicated in Oliveira and Machado (2000). Nonetheless, when the estimation considers both the analysis by quantiles and the type of job breakdown, it adds new information to the empirical analysis in Brazil. Quantile regressions reveal differences between the quantiles of the hourly wage distribution. Mobility has a greater effect on higher paid workers and, depending on the level of disaggregation, a practically nonexistent or negative effect on the poorest. This means that, despite its capacity to raise income, mobility can worsen the distortion of the wage distribution and hinder the expected reduction in income inequality.

\section{Determination of the differential between rich and poor: inter-quantile regressions}

The foregoing results show a higher value for the marginal effect of mobility among the highest-income workers. Bearing this in mind, this subsection presents the estimation of inter-quantile regressions, which evaluate whether this difference between the marginal returns of two conditional quantiles is or is not significant.

Table 7 shows the results for differences between the 10th and 90th quantiles and between the 25th and 75 th. The positive signs, provided the coefficients are significant, indicate that the factor analysed has a greater marginal effect on the hourly wage in the higher quantiles. Thus, they can be interpreted as factors that increase the wage differential between the quantiles being compared, whereas negative signs indicate that the component contributes to a reduction in inequality between points of the distribution. In the case of binary variables, a positive sign on the estimated coefficient can be interpreted as an increase in the inter-quantile hourly wage differential in relation to the reference category.

Among the variables used in the models, only the regional and formality dummy variables display negative signs, which indicates that the difference between the richest and poorest workers could be narrowing as a result of the convergence of regional wages and formalization, among other causes. In the case of informality, this fact can help to explain the recent fall in inequality in the country, because the percentage of informal jobs has also been systematically declining (Mello and Santos, 2009). This provides an additional test of the role played by institutional protection, particularly in balancing out the differences between the extremes of income distribution. Once again, this effect raises the need for new studies on the role of segmentation between formal and informal jobs

TABLE 6

Brazil: marginal effects of mobility for formal and informal workers by quantiles, 2002-2010

\begin{tabular}{|c|c|c|c|c|c|c|c|c|}
\hline \multirow{2}{*}{ Quantiles } & \multicolumn{4}{|c|}{ Formal sectors } & \multicolumn{4}{|c|}{ Informal sectors } \\
\hline & 10th & 25 th & 75 th & 90th & 10th & 25 th & 75 th & 90th \\
\hline Upward & $\begin{array}{r}0.0183^{\mathrm{a}} \\
(0.0066)\end{array}$ & $\begin{array}{r}0.0325^{\mathrm{a}} \\
(0.0086)\end{array}$ & $\begin{array}{r}0.1404^{\mathrm{a}} \\
(0.0141)\end{array}$ & $\begin{array}{r}0.0912^{\mathrm{a}} \\
(0.0178)\end{array}$ & $\begin{array}{l}-0.0102 \\
(0.0333)\end{array}$ & $\begin{array}{c}0.0201 \\
(0.0178)\end{array}$ & $\begin{array}{r}0.0803^{b} \\
(0.0328)\end{array}$ & $\begin{array}{r}0.1337^{\mathrm{a}} \\
(0.0367)\end{array}$ \\
\hline Downward & $\begin{array}{r}0.0165^{\mathrm{a}} \\
(0.0062)\end{array}$ & $\begin{array}{r}0.0408^{\mathrm{a}} \\
(0.0093)\end{array}$ & $\begin{array}{r}0.1379^{\mathrm{a}} \\
(0.0173)\end{array}$ & $\begin{array}{r}0.1059^{\mathrm{a}} \\
(0.0241)\end{array}$ & $\begin{array}{l}-0.0360 \\
(0.0224)\end{array}$ & $\begin{array}{l}-0.0146 \\
(0.0139)\end{array}$ & $\begin{array}{c}0.0313 \\
(0.0294)\end{array}$ & $\begin{array}{c}0.0464 \\
(0.0363)\end{array}$ \\
\hline
\end{tabular}

Source: prepared by the authors on the basis of data from the Monthly Employment Survey.

a $\mathrm{p}<0.01$.

b $\mathrm{p}<0.05$.

Note: robust standard deviations obtained by bootstrapping in parentheses. 
TABLE 7

Brazil: inter-quantile regressions, 2002-2010

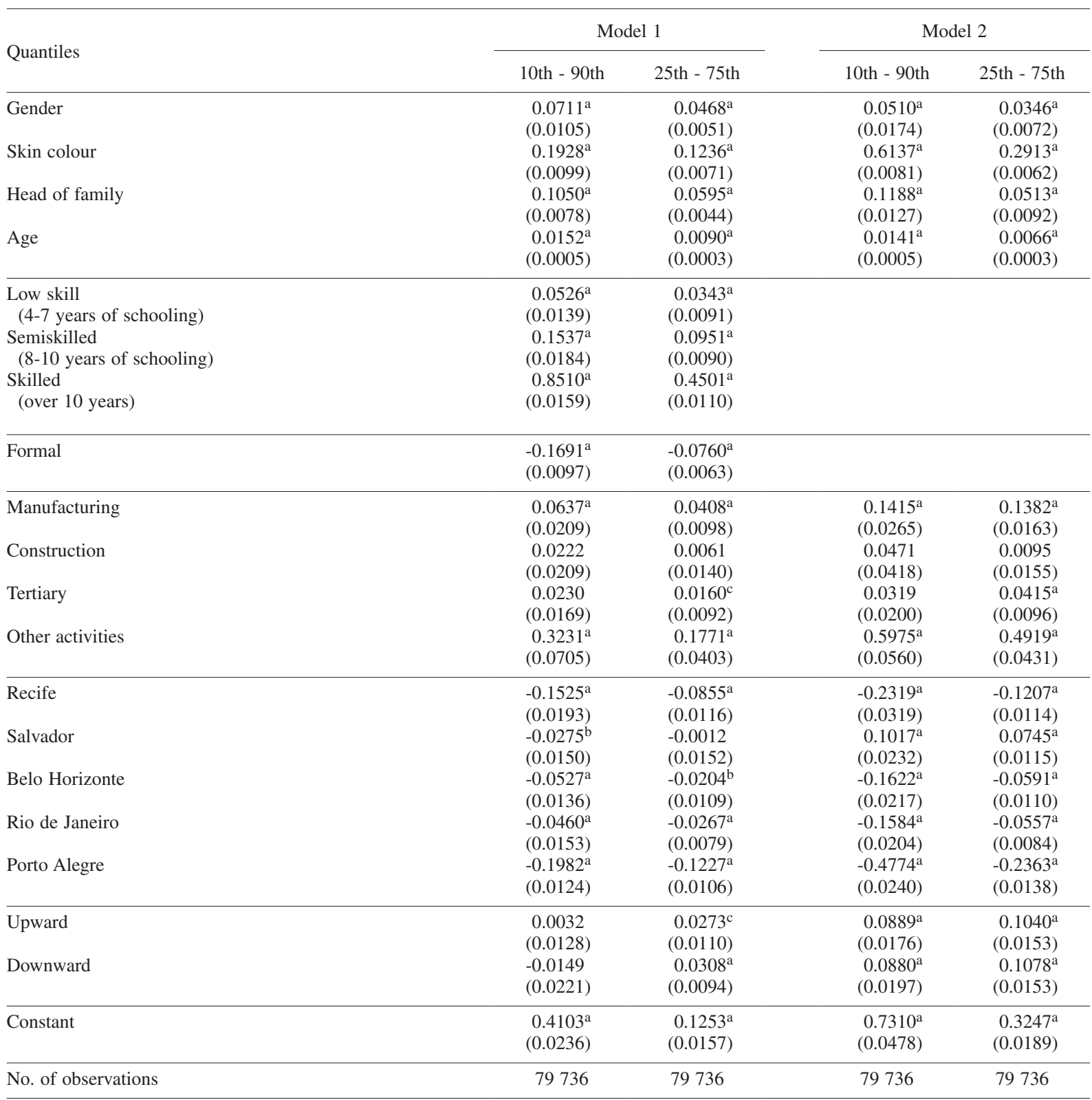

Source: prepared by the authors on the basis of data from the Monthly Employment Survey.

a $\mathrm{p}<0.01$.

b $\mathrm{p}<0.10$

c $\mathrm{p}<0.05$.

Note: annual dummy variables suppressed. Robust standard deviations obtained by bootstrapping in parentheses. 
in the labour market, perhaps by expanding the analysis performed by Curi and Menezes-Filho (2004), which investigated the transition of workers between these two segments, and unemployment and inactivity, but without analysing the repercussion these shifts have on labour incomes. According to the data presented in this study, a significant relation between the mobility of formal and informal jobs and income inequality can be posited.

The variables that capture the transitions between the socio-employment segments defined in the study display positive and significant signs in the vast majority of cases, which confirms that the return or wage premium from mobility is higher among workers in the higher income brackets.

If the data analysed above are considered jointly, the results show that mobility has had a twin effect on workers' wages: firstly by increasing incomes, and secondly helping to widen wage differences. In other words, if two different groups of workers are compared, one consisting of individuals who have recently changed occupational segment and the other with those that have remained in the same category during both evaluation periods, the first group has a higher hourly wage, particularly in the case of individuals whose job change was upwards. Nonetheless, the wage premium resulting from this change, measured in terms of the marginal effect of the dummy variables representing mobility, is significantly larger among higher-paid workers than for those with an hourly wage in the lower part of the distribution. This shows that the highest-earning workers benefit more from job changes than the poorest, or that the former are better able to turn this change into a wage premium, even when the change is to a lower occupational category.

Thus, if the return to mobility is different and more favourable to workers in the upper part of the income distribution, mobility, as it has occurred up to now, seems to help widen the wage gap between rich and poor workers.

If the results show that mobility between segments helps to increase the difference between high income workers and the most poor, how can the recent reduction in inequality be explained? In reality, these facts can be seen as complementary rather than contradictory, because the most plausible explanation is that the labour market in Brazil has acted as a creator of inequalities, thereby hindering the distributive effects of the more favourable macroeconomic environment of the last two years. A significant cause of this limitation, therefore, consists of the way the labour market has encouraged workers to change from one job to another or from one occupational segment to another.

Table 8 shows the estimated coefficients when the worker sample is divided into formal and informal segments. The signs of the inter-quantile difference remain positive and are mostly significant, only varying in terms of intensity. Mobility between socio-employment segments has a greater effect on the gap between the extremes of the wage distribution among informal workers. These results seem to show that occupational mobility among the highest-paid workers could be being used mainly as a strategy for obtaining larger wage increases, because it only happens when the impact on the wage is sufficient to cover the opportunity cost of stability. In contrast, the poorest workers may be using mobility as a social survival strategy.

In short, the results show that mobility between socio-employment segments has a twin effect in the labour market. Firstly, workers use this mechanism to obtain wage increases, as an alternative to stability and the accumulation of specific human capital. This confirms the hypothesis that occupational transitions could be

TABLE 8

Brazil: mobility coefficients from the inter-quantile regressions for formal and informal workers

\begin{tabular}{|c|c|c|c|c|}
\hline & \multicolumn{2}{|c|}{ Formal quantiles } & \multicolumn{2}{|c|}{ Informal quantiles } \\
\hline & 10th -90 th & 25 th -75 th & 10th -90 th & 25 th -75 th \\
\hline Upward & $\begin{array}{c}0.0729^{\mathrm{a}} \\
(0.0199)\end{array}$ & $\begin{array}{c}0.1079^{\mathrm{a}} \\
(0.0148)\end{array}$ & $\begin{array}{c}0.1439^{\mathrm{a}} \\
(0.0415)\end{array}$ & $\begin{array}{c}0.0602^{\mathrm{b}} \\
(0.0321)\end{array}$ \\
\hline Downward & $\begin{array}{r}0.0894^{\mathrm{a}} \\
(0.0212)\end{array}$ & $\begin{array}{r}0.0971^{\mathrm{a}} \\
(0.0159)\end{array}$ & $\begin{array}{c}0.0824 \\
(0.0521)\end{array}$ & $\begin{array}{c}0.0459 \\
(0.0344)\end{array}$ \\
\hline
\end{tabular}

Source: prepared by the authors on the basis of data from the Monthly Employment Survey.

a $\mathrm{p}<0.01$.

b $\mathrm{p}<0.10$.

Note: robust standard deviations obtained by bootstrapping in parentheses. 
being used as a way to escape high-risk situations, or also as a means of professional advancement. Secondly, this use has not caused a narrowing of wage differentials between the different strata of the income distribution. This is explained by the fact that workers with the highest wages are better able to turn mobility into significant wage increases.

One possible explanation of this effect could be that, among the highest-wage workers, mobility would only occur when the benefits and exceeded the cost of the change, such as loss of seniority in the previous job and other non-economic costs. For such workers, the change of job or socio-employment segment seems to be more the result of voluntary decisions, in the search for more productive occupational matches, or with the aim of achieving a higher wage return. Among the poorest workers, in contrast, particularly the informal, mobility may reflect other factors, possibly with a greater involuntary component, which forces the worker to change to a job at the same socio-employment level but does not produce a significant marginal effect (Hachen, 1992).

Consequently, despite contributing to a wage increase, this mobility widens the differential between the wages of workers at the extremes of the income distribution. Even when account is taken of recent data showing that mobility can help reduce wage differentials between certain groups (men and women, persons of black and white race, among others) (Monsueto, 2008; Ruesga, Bichara and Monsueto, 2009), the results of this study seem to indicate that those reductions occur within the same group in the distribution. In other words, the wage gap is narrowed between poor men and women and between men and women of higher wages, but not between poor and rich women, for example.

The results seem to call for a new approach to public policies in relation to the labour market, to strengthen the effect of mobility on wage increases and to offset

\section{V}

\section{Final thoughts}

This article starts from the hypothesis that wage inequality in Brazil is not the result of a single factor, but of a set of related factors, including the role of the labour market and the occupational distribution of workers. If the way labour is distributed affects wages, then mobility between occupations and between segments should be capable of changing the country's income distribution. Thus, the effect of the growth in wage disparities. Job creation should prioritize sectors in which mobility can generate benefits for the workers, particularly those of lowest incomes. In that regard, the restructuring or design of new programmes could be based, for example, on the "flexi-security" systems or flexibility with security, directly or indirectly adopted by some European countries (Auer, Berg and Coulibaly, 2005; Andersen and Svarer, 2006). For that purpose, the economy needs to operate so as to grant a certain degree of flexibility to firms when planning the size of their labour force according to the business cycle, but with a system of protection or pensions linked to programmes that update vocational training and labour relocation. At the same time, policies are needed to improve working conditions in jobs with the lowest socio-employment status, such as incentives to increase formalization and real increases in incomes through the minimum wage. As noted by Fontes, Pero and Berg (2012), these segments tend to benefit most from real increases in the minimum wage, which could help to reduce income inequality.

It should also be noted that the analysis undertaken in this article relates to a period of favourable job prospects and real increases in wages in the economy, and that the results could be different at times of economic stagnation, in which the incidence of involuntary mobility tends to be greater, also among formal workers, and there is a greater need for job-protection measures. Similarly, as shown by Firpo and Reis (2007) the policy of raising the minimum wage in real terms defined by Brazilian legislation has helped to reduce inequality. This policy may have been essential for easing the negative effects caused by occupational mobility on wage differentials between the extremes of the income distribution, by limiting wage losses among workers who switch between jobs of lower status, in other words those most affected by mere labour turnover. the research set out to analyse the effect of mobility on wages and on the income differential between the richest and poorest workers, seeking data on the role played by that mobility in the recent reduction in inequality in the country. Data from the Monthly Employment Surveys of 2002 to 2010 were used, applying models representing the probability of mobility between occupation segments 
and quantile regressions on Mincer wage equations, using dummy variables to capture upward and downward movements by the workers.

The analysis provides topics for discussion through new results for the Brazilian case, which show, for example, that the poorest workers display a small and marginal positive effect from mobility compared to the repercussion of the same factor on the wages of higher paid workers. This shows that occupational mobility, as it has occurred in Brazil, does not generate the same benefits for different pay brackets.

Consequently, it can be argued that, among higherpaid workers, mobility only occurs when the benefits of change exceed its costs, such as the loss of specific human capital and other non-economic costs. In other words, voluntary job changes could be more frequent among this part of the labour force, as a result of the search for more lucrative occupational matches. Among the poorest workers, in contrast, the hypothesis is that changes between segments and jobs are more often caused by involuntary movements or mere labour turnover, so that the wage effects are not significant and may even be negative.

Accordingly, mobility among Brazilian workers may contribute to wage increases, because they display positive marginal returns. Nonetheless, it also fuels larger wage differentials between workers at the extremes of the income distribution. Although recent data show that mobility may help reduce wage gaps between certain groups (men and women, persons of black and white race, among others) as noted in Ruesga, Bichara and Monsueto (2009), the results of this study seem to indicate that these reductions occur within the same group of the income distribution. In other words, there is a reduction in the wage gap between poor men and women and between higher paid men and women, but not between poor and rich women, for example. In addition, the models representing the probability of occupational change show that the most flexible workers, in other words the informal, tend to move downward to segments with a lower socio-employment status when they change jobs. This means that the elimination or reduction of institutional protection does not seem to be consistent with income redistribution policies working through the labour market.

Understanding these results would be essential for formulating a set of efficient employment policies that not only improve employability, but also promote an increase in the quality of life for Brazilian workers and reduce social inequalities. It would thus be possible to promote optimal labour-productivity growth and economy-wide competitiveness. At the same time, a policy to raise the minimum wage tends to reduce the negative effects of occupational mobility between workers in jobs of lower socio-employment status, in other words the lowest paid.

\section{Bibliography}

Albuquerque, L.S.G. (2008), "Mobilidade de emprego entre os jovens brasileiros", Rio de Janeiro, Federal University of Rio de Janeiro.

Andersen, T.M. and M. Svarer (2006), "Flexicurity - the Danish labour market model", Ekonomisk Debatt, No. 1.

Auer, P., J.E. Berg and I. Coulibaly (2005), "Is a stable workforce good for productivity", International Labour Review, vol. 144, No. 3, Geneva, International Labour Organization (ILO).

Barros, R.P., A.F. Machado and R.S.P. Mendonça (1997), "A desigualdade da pobreza: estratégias ocupacionais e diferenciais por gênero", Texto para Discussão, No. 453, Rio de Janeiro, Institute of Applied Economic Research (IPEA).

Barros, R.P. and R.S.P. Mendonça (1995), "Os determinantes da desigualdade no Brasil”, Texto para Discussão, No. 377, Rio de Janeiro, Institute of Applied Economic Research (IPEA).

Barros, R., M. de Carvalho and R.S.P. Mendonça (2010), "Determinantes da queda na desigualdade de renda no Brasil", Texto para Discussão, No. 1460, Rio de Janeiro, Institute of Applied Economic Research (IPEA).

(2007), "A queda recente da desigualdade de renda no Brasil", Texto para Discussão, No. 1258, Rio de Janeiro, Institute of Applied Economic Research (IPEA).

Barros, R.P. and others (1997), "Uma avaliação empírica do grau de flexibilidade alocativa do mercado de trabalho brasileiro", Texto para Discussão, No. 499, Rio de Janeiro, Institute of Applied Economic Research (IPEA).
Beccaria, L. and R. Maurizio (2003), "Movilidad ocupacional en Argentina", 6th Congreso Nacional de Estudios del Trabajo, Buenos Aires, Asociación Argentina de Especialistas en Estudios del Trabajo.

Booth, A. and M. Francesconi (1999), "Job mobility in 1990s Britain: does gender matter?", ISER Working Paper Series, No. 1999-26, Essex, Institute for Social and Economic Research.

Buchinsky, M. (1998), "Recent advances in quantile models: a practical guideline for empirical research", The Journal of Human Resources, vol. 33, No. 1, Madison, Wisconsin, University of Wisconsin Press.

Budría, S. and P.T. Pereira (2004), "On the returns to training in Portugal", CEEAPLA, Working Paper Series, No. 01/2004, Bonn.

Cheng, M.M. and A.L. Kalleberg (1996), "Labor market structures in Japan: an analysis of organizational and occupational mobility patterns", Social Forces, vol. 74, No. 4, Oxford, Oxford University Press.

Corseuil, C.H. (ed.) (2002), Estrutura salarial: aspectos conceituais e novos resultados para o Brasil, Rio de Janeiro, Institute of Applied Economic Research (IPEA).

Corseuil, C.H. and M.N. Foguel (2002), "Uma sugestão de deflatores para rendas obtidas a partir de algumas pesquisas domiciliares do IBGE", Texto para Discussão, No. 897, Rio de Janeiro, Institute of Applied Economic Research (IPEA).

Curi, A.Z. and N.A. Menezes-Filho (2004), "Os determinantes das transições ocupacionais no mercado de trabalho brasileiro", 
Anais do XXXII Encontro Nacional de Economia, Rio de Janeiro, National Association of Post-Graduate Centres of Economics (ANPEC).

Davia, M.A. (2006), "Studying the impact of job mobility on wage growth at the beginning of the employment career in Spain", paper presented at the IX Applied Economics Meeting, Jaén.

Dolton, P.J. and M.P. Kidd (1998), "Job changes, occupational mobility and human capital acquisition: an empirical analysis", Bulletin of Economic Research, vol. 50, No. 4, Blackwell Publishing.

Ferrari-Filho, F., A.M. Cunha and J.S. Bichara (2014), "Brazilian countercyclical economic policies as a response to the Great Recession: a critical analysis and an alternative proposal to ensure macroeconomic stability", Journal of Post Keynesian Economics, vol. 36, No. 3, M.E. Sharpe.

Firpo, S. and M.C. Reis (2007), "O salário mínimo e a queda recente da desigualdade no Brasil", Desigualdade de renda no Brasil: uma análise da queda recente (volume 2), R.P. Barros, M.N. Foguel and G. Ulyssea (orgs.), Brasilia, Institute of Applied Economic Research (IPEA).

Fitzenberger, B. and A. Kunze (2005), "Vocational training and gender: wages and occupational mobility among young workers", ZEW Discussion Papers, No. 05-66, Mannheim, Zentrum für Europäische Wirtschaftsforschung (ZEW).

Flore, P. and N. Menezes-Filho (2008), "Mobilidade entre ocupações e efeitos salariais", Anais do XXXVI Encontro Nacional de Economia, Rio de Janeiro, National Association of PostGraduate Centres of Economics (ANPEC).

Fontes, A., V. Pero and J. Berg (2012), "Low-paid employment in Brazil”, International Labour Review, vol. 151, No. 3, Wiley.

Gabriel, P.E. (2003), "An examination of occupational mobility among full-time workers", Monthly Labor Review, vol. 129, No. 9, Washington, D.C., Bureau of Labor Statistics.

García Pérez, J.I. and Y. Rebollo Sanz (2005), "Wages changes through job mobility in Europe: a multinomial endogenous switching approach", Labour Economics, vol. 12, No. 4, Amsterdam, Elsevier.

Hachen, D.S. Jr. (1992), "Industrial characteristics and job mobility rates", American Sociological Review, vol. 57, No. 1, Washington, D.C., American Sociological Association.

Holzer, H.J., J.I. Lane and L. Vilhuber (2003), "Escaping low earnings: the role of employer characteristics and changes", Discussion Paper, No. 1269-03, Institute of Research on Poverty.

IPEA (Institute of Applied Economic Research) (2010), "O Brasil em 4 décadas”, Texto para Discussão, No. 1500, Brasilia.

Jannuzzi, P.M. (2004), "As ocupações brasileiras segundo а сво 2002: caracterização empírica com base no Censo 2000", Revista da ABET, vol. 4, No. 2, Brazilian Association for Labour Research (ABET).

Kambourov, G. and I. Manovskii (2004), "Rising occupational and industry mobility in the United States: 1968-1993", IZA Discussion Paper, No. 1110, Bonn, Institute for the Study of Labor (IZA).

Koenker, R. (2000), Quantile Regression, Illinois, University of Illinois.

Koenker, R. and G. Basset (1978), "Regression quantiles", Econometrica, vol. 46, No. 1, Washington, D.C., The Econometric Society.

Maciel, M.C., A.C. Campelo and M.C.F. Raposo (2001), "A dinâmica das mudanças na distribuição salarial e no retorno em educação para mulheres: uma aplicação de regressão quantílica", Anais do XXIX Encontro Nacional de Economia, Rio de Janeiro, National Association of Post-Graduate Centres of Economics (ANPEC).
Maltseva, I. (2005), "Gender differences in occupational mobility and segregation at the labor market: the case of Russian economy", EERC Working Paper Series, No. 05/11, EERC Research Network.

Matos, R.S.E. and A.F. Machado (2006), "Diferencial de rendimento por cor e sexo no Brasil (1987-2001)", Econômica, vol. 8, No. 1, Rio de Janeiro, Fluminense Federal University.

McLaughlin, K.J. (1991), "A theory of quits and layoffs with efficient turnover", Journal of Political Economy, vol. 99, No. 1, Chicago, University of Chicago Press.

Mello, R.F. and D.D. Santos (2009), "Aceleração educacional e a queda recente da informalidade", Boletim de Mercado de Trabalho, No. 39, Rio de Janeiro, Institute of Applied Economic Research (IPEA).

Menezes-Filho, N. (2004), "The costs of displacement in Brazil", XXVI Encontro Brasileiro de Ecomometria, João Pessoa, Brazilian Society of Econometrics.

Mincer, J. and B. Jovanovic (1979), "Labor mobility and wages", NBER Working Paper, No. 357, Cambridge, Massachusetts, National Bureau of Economic Research.

Monsueto, S.E. (2008), "Movilidad ocupacional e impactos sobre la renta en Brasil", Ph.D. Thesis, Madrid, Autonomous University of Madrid.

Neri, M. and others (1997), "Aspectos dinâmicos do desemprego e da posição na ocupação", Encontro Nacional de Estudos do Trabalho, Rio de Janeiro, Brazilian Association for Labour Research (ABET).

Oliveira, A.M.H.C. (2003), "A segregação ocupacional por gênero e seus efeitos sobre os salários no Brasil", Mercado de trabalho: uma análise a partir das pesquisas domiciliares no Brasil, S. Wajnman and A.F. Machado (orgs.), Belo Horizonte, Editora UFMG.

(1998), "Indicadores da segregação ocupacional por sexo no Brasil", Anais do XI Encontro Nacional de Estudos Populacionais, Brazilian Association for Population Studies (ABEP).

Oliveira, A.M.H.C. and A.F. Machado (2000), "Mobilidade ocupacional e rendimentos no Brasil metropolitano: 1991/96", Pesquisa e Planejamento Econômico, vol. 30, No. 1, Institute of Applied Economic Research (IPEA).

Oliveira, A.M.H.C. and P.M. Ribeiro (1998), "Diferenciais ocupacionais por raça e gênero no mercado de trabalho metropolitano no Brasil", XI Encontro Nacional de Estudos Populacionais, Brazilian Association for Population Studies (ABEP).

Orellano, V. and P. Picchetti (2001), "A bi-variate probit analisys of job turnover in Brazil", XXIII Encontro Brasileiro de Econometria, Salvador, Brazilian Society of Econometrics.

Paci, P. and P. Serneels (ed.) (2007), Employment and Shared Growth: Rethinking the Role of Labor Mobility for Development, Washington, D.C., World Bank.

Parrado, E., A. Caner and E. Wolff (2007), "Occupational and industrial mobility in the United States", Labour Economics, vol. 14, No. 3, Amsterdam, Elsevier.

Parrado, E. and E. Wolff (1999), "Occupational and industry mobility in the United States, 1969-1992", Working Papers, No. 99-20, New York, C.V. Starr Center for Applied Economics, New York University.

Pianto, M.T. and D.M. Pianto (2002), "Informal employment in Brazil - a choice at the top and segmentation at the bottom: a quantile regression approach", Textos para Discussão, No. 236, Brasilia, Economics Department/University of Brasilia.

Pinto, A. and M. Neri (2000), "Mobilidade ocupacional e raça: origens, destinos e riscos dos afro-brasileiros", Ensaios Econômicos, No. 392, Rio de Janeiro, Getulio Vargas Foundation. 
Ribas, R.P. and S.D.S. Soares (2008), "Sobre o painel da pesquisa mensal de emprego (PME) do IBGE", Texto para Discussão, No. 1348, Rio de Janeiro, Institute of Applied Economic Research (IPEA).

Rocha, S. (2000), "Pobreza e desigualdade no Brasil: o esgotamento dos efeitos distributivos do Plano Real", Texto para Discussão, No. 721, Rio de Janeiro, Institute of Applied Economic Research (IPEA).

Ruesga, S.B., J.S. Bichara and S.E. Monsueto (2009), "Diferencial de gênero e efeitos da mobilidade socioeconômica", XXXVII Encontro Nacional de Economia, Rio de Janeiro, National Association of Post-Graduate Centres of Economics (ANPEC).
Sampaio, A.V. (2009), "Estimação da equação de salário para o Brasil, o Paraná e o Rio Grande do Sul em 2007 - uma abordagem quantílica", Indicadores Econômicos FEE, vol. 37, No. 2, Porto Alegre, Fundação de Economia e Estatística.

Soares, C. and S. Oliveira (2004), "Gênero, estrutura ocupacional e diferenciais de rendimento", Econômica, vol. 6, No. 1, Rio de Janeiro, Fluminense Federal University.

Souza, E.C. and J.E. Lima (2011), "Condição de ocupação e informalidade no mercado de trabalho brasileiro em 2007", Análise Econômica, vol. 29, No. 56, Porto Alegre, Federal University of Rio Grande do Sul (UFRGS).

Zimmermann, K.F. (1998), "German job mobility and wages", IZA Discussion Papers, No. 4, Bonn, Institute for the Study of Labor. 